\title{
Science Teachers' Knowledge of Nutrition Facts on Canned Foods and its implications during the COVID-19 Pandemic
}

\author{
Sameera Alshorman ${ }^{1 *}$, Esra'a Abu-Nijem ${ }^{23}$ \\ ${ }^{1}$ Assistant Professor at the Arab Open University, Jordan \\ ${ }^{2}$ Stage cycle leader at AI QIMMA International School, Jordan
}

\section{Abstract}

This study investigates the extent of science teachers' knowledge of canned foods. In the study, quantitative research design was adopted. An electronic questionnaire was administered to 56 teachers from various majors of Science, and from medical specialties on voluntary basis that were selected using purposive sampling method. In addition, 10 interviews were conducted with 10 randomly selected teachers among the participant teachers in order to clarify the effects of gender and monthly income on the choice of canned foods in the market, particularly during the time of COVID - 19 pandemic. Results revealed that there were significant differences in participant's knowledge of nutrition labels for the canned foods attributed of gender in most of the questions. On other side, there were no significant differences in participant's knowledge of nutrition labels for the canned foods attributed to monthly income.

Keywords: Science teachers, canned foods, nutrition labels, science education

\section{Introduction}

In March of 2020, the World Health Organization had officially declared the outbreak of Coronavirus (COVID-19) a pandemic (World Health Organization, 2020). Soon after that, events accelerated rapidly and countries all over the world started taking extreme measures to protect the lives of their citizens. Those measures were characterized by strict social distancing and included the shutdown of public places and facilities such as shopping malls, cinemas, theatres, airports, schools and universities.

During the time period that preceded the COVID-19 lock-down, many people around the world were panicking. Thus, they started purchasing and stock-pilling products such as water, gloves, and carbohydrate-rich staples such as bread, canned foods, disinfectants, and even toilet paper. (Mao, 2020).

According to (Bracale \& Vaccarob, 2020), during the first two months of the COVID-19 look-down, the world witnessed a significant spike in the consumption of canned foods in addition to other items such as, pasta, flour, eggs, long-life pasteurized milk and frozen foods. This came along with a noticeable decrease in the consumption of fresh goods, such as fruit and vegetables.

The COVID-19 pandemic has had a massive impact people's lifestyle. Nearly one in two citizens reported increasing their food intake and consuming comfort food to improve their feelings. Consequently, this made them feel worried because of their poor eating habits (Di Renzo, et al., 2020) \& (Scarmozzino \& Visioli , 2020).

The concept of nutrition has interdisciplinary nature and affects all other parts of our lives and livelihoods. Therefore, it should not be left to nutrition teachers only. Quite the reverse, due to its high importance, nutrition education should be handled with an interdisciplinary approach. Interdisciplinary nutrition education was found to have a positive effect on students' lifestyle and health choices. (Mertoglu, 2019)

\section{Definition of terms}

Knowledge: The acquired knowledge and experiences of the participants towards nutritional facts and food labels and how they utilize it in their science classes.

Nutritional facts: The nutritional information written on food labels such as: Ingredients, food additives and calories.

\section{Science teachers and health literacy:}

Health Literacy has been defined as "the degree to which an individual has the capacity to obtain, communicate, process, and understand basic health information and services to make appropriate health decisions." (Health Literacy Basics, 2020).

Science teachers are the main professionals in schools who address health-related subjects. Encouraging technicalscientific knowledge of food and nutrition among teachers will arguably results in the enhancement of the school as

Corresponding Author e-mail: sameera.shurman@hotmail.com https://orcid.org/0000-0003-2880-5284

How to cite this article: Alshorman S, Abu-Nijem E, (2021). Science Teachers' Knowledge of Nutrition Facts on Canned Foods and its implications during the COVID-19 Pandemic. Pegem Journal of Education and Instruction, Vol. 11, No. 4, 2021, 67-77

Source of support: Nil

Conflict of interest: None.

DOI: $10.47750 /$ pegegog.11.04.07

Received: 16.05 .2021

Accepted: 29.06.2021 Publication: 01.10.2021 
an environment for health promotion (Netto Rangel, Nunn, Dysarz, Silva, \& Brasil Fonseca, 2014).

According to (Choi, Bae, Kim, \& In, 2010), nutritional knowledge has a significant effect on dietary habits. Moreover, reliable and methodical supervision is necessary under the official support by the school to enhance the awareness of student concerning nutrition and to cultivate effective nutrition education (Şahin-Kalyon, 2021).

Due to the constant interaction between teachers and students, the degree of health literacy of the teachers may also have an impact on the degree of health literacy of the students. (Atay, et al., 2018). Therefore, Teachers' health literacy is essential to the overall wellbeing of the teachers themselves and their students as well.

Therefore, it is essential for science teachers to enrich their teaching with nutrition information that help students make good choices of their consumed food specially canned foods at the quarantine time because of the COVID-19 crisis and beyond.

\section{Teachers' Knowledge of Nutrition Facts:}

Teachers' personal experience and level of commitment to nutrition education are significant factors in influencing adolescents to change food consumption habits in a positive way. (Lewis, Brun, Talmage, \& Rasher, 1988). In a study on 628 elementary public-school teachers conducted by (Metos, Sarnoff, \& Jordan, 2018), 68\% of teachers agreed that they can make a difference in the eating behaviors of their students. However, only $21 \%$ of them agreed that they have support to teach nutrition in the classroom.

Interestingly, (Unusan, 2004) confirmed that the more teachers know about nutrition labels and the terms used in them, the more they seemed be interested in them. Thus, nutrition education can help teachers to use nutrition labels to improve the quality of their diets. In an extensive classic study by (Karen P.Penner, 1983), 1,191 teachers were surveyed for their nutrition knowledge, attitudes, and practices. They found that about $70 \%$ of the teachers reported teaching something about food or nutrition. Additionally, their results showed that the teachers who actively educated their students about food or nutrition had taken more food or nutrition courses, had higher knowledge scores, and had more favorable attitudes toward teaching nutrition.

Despite their awareness of the importance of having a healthy food environment in the school, many teachers engage in classroom practices and behaviors that do not promote healthy eating, thus reflecting negatively on the healthy choices and eating habits of their students (Findholt, Izumi, Shannon, \& Naguyen, 2016). Furthermore, many teachers did not reflect a positive example of healthy eating behaviors at school. According to (Kubik, Lytle, Hannan, Story , \& Perry, 2009), low perceived personal health, low support for the school food environment, and high-fat scores were a few of the major correlates of teachers' eating behavior.

Science teachers and teachers in general need to be more proactive in their approach to nutrition facts and healthy lifestyle. Unfortunately, (Sekiyama, 2019) found that most teachers in elementary and secondary stages do not adopt a healthy lifestyle, only until they get chronic disease such as diabetes or hypertension. After that and because of those diseases, they start to take more conscious decisions by reading food labels according to medical advice to check the calories in the food. Ironically, one of the major reasons of their diseases in the first place was the poor food choices and the poor health lifestyle, especially when it comes to choices for canned and processed food.

Teachers who read food labels on a regular basis are comparatively younger, at the age of 25-40 years, and they are mainly university graduates (Unusan, 2004). The frequent use of nutritional labels was significantly associated with female sex and the highest monthly family income level (Montagna Sekiyama, Rodrigues, Eumann Mesas, Durán González, \& Maffei de Andrade, 2009). This was one of the reasons to investigate and explore aspects of gender and income, we asked more than 100 science teachers from private and government schools and only 56 of the teachers participated in the survey $76.6 \%$ of the participants were female science teachers and $23 \%$ of the participants were male science teachers and some other medical teaching majors (nursing, Ph.D. teachers in university) as shown in the following pi diagrams in chart 1 as well chart 2

\section{Research Objectives, Questions, and Definition of Terms}

Science teachers are an essential part of the educational system in the 21st century. They are at the forefront of teaching

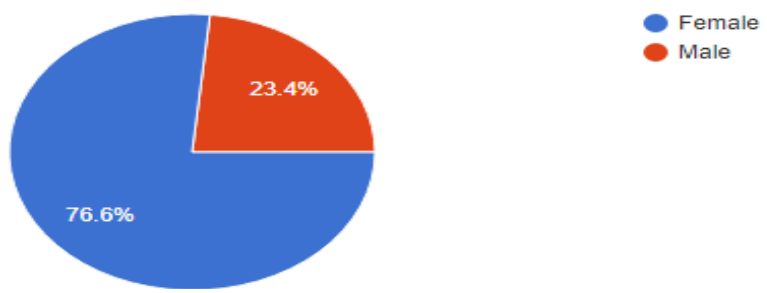

Chart 1: Gender

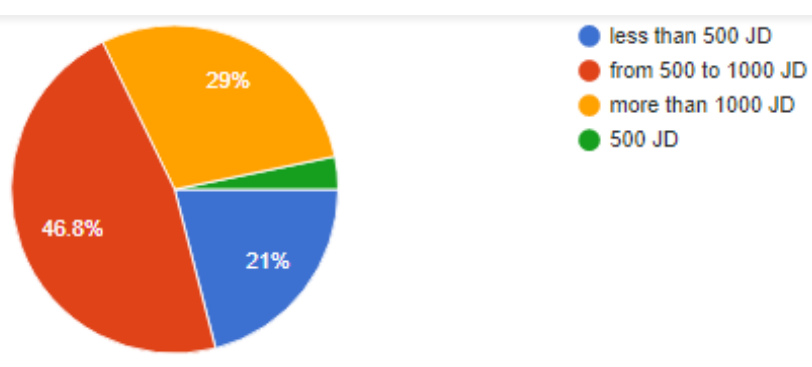

Chart 2: monthly income 
students the topics of the future. At the same time, students look up to them as role models and trusted sources of facts and valuable life information. However, their influence on students does not stop at the end of the curriculum only; they can have a major impact on the overall habits and lifestyle of their student's as well. Moreover, there is limited research in the area of primary, middle as well as high school science teacher's knowledge of food labels and nutritional facts both globally and in the Middle East region. Two articles were declared about the subject but only the first was published in October, 2010 confirmed that educators identified their healthy eating skills and acknowledgment from different resources such as television, internet and cooking programs but not from school programs (Fordyce-Voorham, 2011)

This issue has become more prominent during the time of the COVID-19 crisis and its broad implications on the eating habits and lifestyle of citizens all over the world.

Within the scope of this research, answers to the following questions were sought:

- Do science teachers read food labels and nutritional facts?

- Do science teachers teach their students about food labels and nutritional facts - although it might not be required in the curriculum?

- Is there a significant relationship between science teachers' gender and their knowledge of food labels and nutritional facts?

- Is there a significant relationship between science teachers' income levels and their knowledge of food labels and nutritional facts?

- Is there a significant relationship between the consumption of canned foods and the COVID -19 pandemic?

\section{Methodology}

\section{Research design}

The aim of the study was to investigate the science teachers' knowledge about nutritional facts and food labels. The study adopted quantitative research design.

\section{Participants}

The participants of the study were selected via purposive method, and were composed of 56 volunteer science teachers and teachers with medical major (42 females, 14 males). The participants were selected amongst higher diploma students at the Arab Open University - Jordan Branch. In the study, the online questionnaire was sent to 63 teachers but 56 of them responded the questionnaire (89\%).

\section{Data collection tools}

The data were collected using two instruments, a questionnaire form and an interview form, both of which were developed by the researcher. According to (Harris \& Brown, 2010) questionnaires can offer a great help in providing verification of patterns between large populations.
- Questionnaire form: The items in the questionnaire form were constructed by then researcher based on the review of the relevant literature considering the framework of the study. It comprised of two main parts: demographic information (gender, age, type of schools: private or public and the level of monthly income), and science teachers' knowledge of nutritional facts and food labels. In designing the questionnaire, a Likert's 3-point scale was utilized: Yes, No and Maybe.

Interview form: In the study an interview form, developed by the researcher, was also administered to randomly selected ten volunteer teachers (5 females and 5 males) among the participant teachers whose majors were general science, biology, medical science (nursing), chemistry and biochemistry teaching in middle and high school levels as it is shown in chart 3.

To ensure the validity of the research instrument, the questionnaire was presented to a jury of three experts in science education, two experts in nutrition and two specialists in measurement and assessment. The feedback from the jury was positive with some comments on rephrasing or clarifying some items. All of their remarks were honoured in the final version of the research instrument.

To measure the reliability of the research tool, a trial study was conducted that used the Cronbach alpha coefficient. The research tool consisted of 22 items; the Cronbach alpha coefficient was 0.79 , which reveals that the internal consistency of the research tool was considered suitable for the purposes of this study. The reliability of the research instrument was similarly verified through the test- retest method on a trial study that consisted of 16 science teachers. The timeframe between the two tests was two weeks, and the results between the two tests were measured using Pearson's' correlation coefficient. The result was 0.81 , and it is suitable for the purpose of this research study.

\section{Data collection and analysis}

The questionnaire was sent to participants using the Learning Management System (LMS) of the university in 2019-2020 academic year. In the study, the same open-ended questions were asked to all interviewees (an open-ended question is

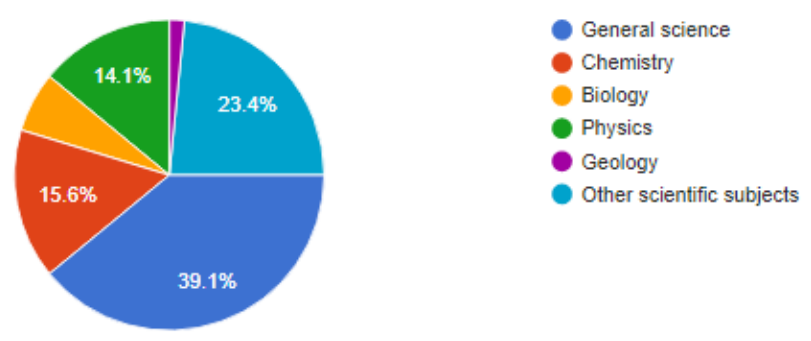

Chart 3: $x x x x x x x x x x x x$ 
where respondents are free to choose how to answer the question, i.e., they don't select "yes" or "no" or provide a numeric rating, etc.); this approach facilitated faster interviews that could be analyzed and compared easily.

The participants were provided with a comprehensive clarification about the purpose of the study during the lectures, and they were invited to participate voluntarily. They were also informed that the data were confidential and would be used for the research purposes, and they could withdraw from completing the questionnaire items at any time. Data were then sorted and reviewed. The analysis was conducted using the Statistical Package for Social Sciences (SPSS) software - version 25. Descriptive statistics was used to answer the research questions.

\section{Results}

\section{Descriptive Statistics:}

The purpose of this study was to investigate the relationship between science teacher's knowledge about nutritional facts of canned foods \& gender; the results of the study are presented as follows:

Table (1) presents a complete list of respondents' demographic characteristics in terms of gender, income, workplace \& subject.
Table (1) shows that: $25 \%$ of the study samples were males and $75 \%$ of the study samples were females. It is known that nutrition as a science can usually be dated from the work of Lavoisier about 200 years ago; the emergence of studies of human nutrient requirements coincides with the entry of women into the science in the early 1900s. Mostly woman tend

Table 1: Demographic Characteristics of Respondents.

\begin{tabular}{lllll}
\hline Variable & Category & Frequency & Percentage \\
\hline Gender & Male & 14 & $25 \%$ \\
& Female & 42 & $75 \%$ \\
Income & Less than 500 JD & 12 & $21.4 \%$ \\
& $500-1000 \mathrm{JD}$ & 27 & $48.2 \%$ \\
& More than 1000 JD & 17 & $30.4 \%$ \\
Workplace & Government School & 7 & $12.5 \%$ \\
& Private school & 49 & $87.5 \%$ \\
& General science & 22 & $39.3 \%$ \\
& Chemistry & 8 & $14.35 \%$ \\
& Biology & 4 & $7.1 \%$ \\
& Physics & 8 & $14.3 \%$ \\
& Geology & 1 & $1.8 \%$ \\
& Other scientific subjects & 13 & $23.2 \%$ \\
\hline
\end{tabular}

Table 2: Science teacher's knowledge about nutritional facts of canned foods from different gender

\begin{tabular}{|c|c|c|c|c|c|c|c|}
\hline No. & Question & Answer & Male & Female & Total & Chi square & $p$-value \\
\hline \multirow[t]{3}{*}{1} & \multirow{3}{*}{$\begin{array}{l}\text { Is canned foods as nutritious as fresh and frozen } \\
\text { food? }\end{array}$} & Yes & $4(28.6 \%)$ & $1(2.4 \%)$ & $5(8.9 \%)$ & \multirow[t]{3}{*}{9.85} & \multirow[t]{3}{*}{$0.007^{*}$} \\
\hline & & Maybe & $5(35.7 \%)$ & $13(31 \%)$ & $18(32.1 \%)$ & & \\
\hline & & No & $5(35.7 \%)$ & $28(66.7 \%)$ & $33(58.9 \%)$ & & \\
\hline \multirow[t]{3}{*}{2} & \multirow{3}{*}{$\begin{array}{l}\text { Do you know how to choose canned foods by using } \\
\text { the food labels on the back of the can? }\end{array}$} & Yes & $9(64.3 \%)$ & $29(69 \%)$ & $38(67.9 \%)$ & \multirow[t]{3}{*}{0.113} & \multirow[t]{3}{*}{0.945} \\
\hline & & Maybe & $2(14.3 \%)$ & $5(11.9 \%)$ & $7(12.5 \%)$ & & \\
\hline & & No & $3(21.4 \%)$ & $8(19 \%)$ & $11(19.6 \%)$ & & \\
\hline \multirow[t]{3}{*}{3} & \multirow{3}{*}{$\begin{array}{l}\text { Do you know the difference between canned tuna } \\
\text { with oil and canned tuna with salty water? }\end{array}$} & Yes & $9(64.3 \%)$ & $31(73.8 \%)$ & $40(71.4)$ & \multirow[t]{3}{*}{0.475} & \multirow[t]{3}{*}{0.789} \\
\hline & & Maybe & $1(7.1 \%)$ & $2(4.8 \%)$ & $3(5.4 \%)$ & & \\
\hline & & No & $4(28.6 \%)$ & $9(21.4 \%)$ & $13(23.2 \%)$ & & \\
\hline \multirow[t]{3}{*}{4} & \multirow{3}{*}{$\begin{array}{l}\text { Do you know how to read the labels on the back } \\
\text { of the canned foods? }\end{array}$} & Yes & $9(64.3 \%)$ & $36(85.7 \%)$ & $45(80.4 \%)$ & \multirow[t]{3}{*}{6.22} & \multirow[t]{3}{*}{$0.045^{\star}$} \\
\hline & & Maybe & $1(7.1 \%)$ & $4(9.5 \%)$ & $5(8.9 \%)$ & & \\
\hline & & No & $4(28.6 \%)$ & $2(4.8 \%)$ & $6(10.7 \%)$ & & \\
\hline \multirow[t]{3}{*}{5} & \multirow{3}{*}{$\begin{array}{l}\text { Have you ever counted the calories that the canned } \\
\text { foods provide for one meal? } \\
\text { Have you ever counted the calories that the canned } \\
\text { foods provide for one meal? }\end{array}$} & Yes & $7(50 \%)$ & $17(40.5 \%)$ & $24(42.9 \%)$ & \multirow[t]{3}{*}{1.56} & \multirow[t]{3}{*}{0.459} \\
\hline & & Maybe & 0 & $4(9.5 \%)$ & $4(7.1 \%)$ & & \\
\hline & & No & $7(50 \%)$ & $21(50 \%)$ & $28(50 \%)$ & & \\
\hline \multirow[t]{3}{*}{6} & \multirow{3}{*}{$\begin{array}{l}\text { Do you think that canned foods are high in } \\
\text { sodium? }\end{array}$} & Yes & $7(50 \%)$ & $29(69 \%)$ & $36(64.3 \%)$ & \multirow[t]{3}{*}{5.93} & \multirow[t]{3}{*}{$0.052^{*}$} \\
\hline & & Maybe & $4(28.6 \%)$ & $12(28.6 \%)$ & $16(28.6 \%)$ & & \\
\hline & & No & $3(21.4 \%)$ & $1(2.4 \%)$ & $4(7.1 \%)$ & & \\
\hline \multirow[t]{3}{*}{7} & \multirow{3}{*}{$\begin{array}{l}\text { Have you ever taught your students facts about } \\
\text { canned foods? }\end{array}$} & Yes & $4(28.6 \%)$ & $12(28.6 \%)$ & $16(28.6 \%)$ & \multirow[t]{3}{*}{0.320} & \multirow[t]{3}{*}{0.852} \\
\hline & & Maybe & $7(50 \%)$ & $18(42.9 \%)$ & $25(44.6 \%)$ & & \\
\hline & & No & $3(21.4 \%)$ & $12(28.6 \%)$ & $15(26.8 \%)$ & & \\
\hline
\end{tabular}




\begin{tabular}{|c|c|c|c|c|c|c|c|}
\hline No. & Question & Answer & Male & Female & Total & Chi square & $p$-value \\
\hline \multirow[t]{3}{*}{8} & \multirow{3}{*}{$\begin{array}{l}\text { Do you explain to your students the bad effects of } \\
\text { canned foods when over consumed? }\end{array}$} & Yes & $5(35.7 \%)$ & $23(54.8 \%)$ & $28(50 \%)$ & 4.10 & 0.129 \\
\hline & & Maybe & 0 & $4(9.5 \%)$ & $4(7.1 \%)$ & & \\
\hline & & No & $9(64.3 \%)$ & $15(35.7 \%)$ & $24(42.9 \%)$ & & \\
\hline \multirow[t]{3}{*}{9} & \multirow{3}{*}{$\begin{array}{l}\text { Do you think that the science curriculum should } \\
\text { contain lessons about food labels facts? }\end{array}$} & Yes & $10(71.4 \%)$ & $40(95.2 \%)$ & $50(89.3 \%)$ & 6.93 & $0.031^{\star}$ \\
\hline & & Maybe & $3(21.4 \%)$ & $2(4.8 \%)$ & $5(8.9 \%)$ & & \\
\hline & & No & $1(7.1 \%)$ & 0 & $1(1.8 \%)$ & & \\
\hline \multirow[t]{3}{*}{10} & \multirow{3}{*}{$\begin{array}{l}\text { Do you think teaching information about food } \\
\text { labels will add long-life experience towards healthy } \\
\text { diets? }\end{array}$} & Yes & $11(78.6 \%)$ & $37(88.1 \%)$ & $48(85.7 \%)$ & 3.16 & 0.206 \\
\hline & & Maybe & $2(14.3 \%)$ & $5(11.9 \%)$ & $7(12.5 \%)$ & & \\
\hline & & No & $1(7.1 \%)$ & 0 & $1(1.8 \%)$ & & \\
\hline \multirow[t]{3}{*}{11} & \multirow{3}{*}{$\begin{array}{l}\text { Through the COVID-19 crisis, do you think that } \\
\text { consuming more canned foods may cause health } \\
\text { issues for people? }\end{array}$} & Yes & $4(28.6 \%)$ & $27(64.3 \%)$ & $31(55.4 \%)$ & 5.67 & 0.059 \\
\hline & & Maybe & $8(57.1 \%)$ & $13(31 \%)$ & $21(37.5 \%)$ & & \\
\hline & & No & $2(14.3 \%)$ & $2(4.8 \%)$ & $4(7.1 \%)$ & & \\
\hline \multirow[t]{3}{*}{12} & Do you think consuming more canned foods & Yes & $5(35.7 \%)$ & $16(38.1 \%)$ & $21(37.5 \%)$ & 0.400 & 0.819 \\
\hline & & Maybe & $6(42.9 \%)$ & $20(47.6 \%)$ & $26(46.4 \%)$ & & \\
\hline & & No & $3(21.4 \%)$ & $6(14.3 \%)$ & $9(16.1 \%)$ & & \\
\hline \multirow[t]{3}{*}{13} & \multirow[t]{3}{*}{ Does canned foods cause chronic diseases? } & Yes & $1(7.1 \%)$ & $9(21.4 \%)$ & $1017.9 \%)$ & 5.48 & 0.064 \\
\hline & & Maybe & $6(42.9 \%)$ & $25(59.5 \%)$ & $31(55.4 \%)$ & & \\
\hline & & No & $7(50 \%)$ & $8(19 \%)$ & $15(26.8 \%)$ & & \\
\hline \multirow[t]{3}{*}{14} & \multirow{3}{*}{$\begin{array}{l}\text { From your point of view as a science teacher, do you } \\
\text { think that canned foods have any genetic effects on } \\
\text { the new off springs? }\end{array}$} & Yes & $2(14.3 \%)$ & $10(23.8 \%)$ & $12(21.4 \%)$ & 1.35 & 0.508 \\
\hline & & Maybe & $5(35.7 \%)$ & $18(42.9 \%)$ & $23(41.1 \%)$ & & \\
\hline & & No & $7(50 \%)$ & $14(33.3 \%)$ & $21(37.5 \%)$ & & \\
\hline \multirow[t]{3}{*}{15} & \multirow{3}{*}{$\begin{array}{l}\text { Do you recommend your colleagues to add extra- } \\
\text { curricular about health issues that help their } \\
\text { students to boost the immune system and fight } \\
\text { the new virus? }\end{array}$} & Yes & $13(92.9 \%)$ & $37(88.1 \%)$ & $50(89.3 \%)$ & 0.693 & 0.707 \\
\hline & & Maybe & 0 & $2(4.8 \%)$ & $2(3.6 \%)$ & & \\
\hline & & No & $1(7.1 \%)$ & $3(7.1 \%)$ & $4(7.1 \%)$ & & \\
\hline \multirow[t]{3}{*}{16} & \multirow{3}{*}{$\begin{array}{l}\text { Have you ever explained to your students the } \\
\text { Bisphenol A that is present in canned foods? }\end{array}$} & Yes & $1(7.1 \%)$ & $3(7.1 \%)$ & $4(7.1 \%)$ & 0.340 & 0.844 \\
\hline & & Maybe & 0 & $1(2.4 \%)$ & $1(1.8 \%)$ & & \\
\hline & & No & $13(92.9 \%)$ & $38(90.5 \%)$ & $51(91.1 \%)$ & & \\
\hline
\end{tabular}

to study issues connected to their concerns such as (children and food) which made the results more realistic that female science teachers rather to participate in the research more than men (King, 2003).

$21.4 \%$ from the sample their monthly income less than 500 JD, $48.2 \%$ their monthly income between 500-1000 JD, 30.4\% their monthly income more than 1000 JD. $12.5 \%$ from the sample work in government schools, and $87.5 \%$ work in private schools. The result can show clearly that there is a gap between male and female incomes since $75 \%$ of the science teachers participants were female and through checking accurately the names and majors, it was found that the range of incomes less than 500JD for females that work in private schools and had few years of experience in teaching as well as the income between 500-1000 were contrasted between females and males that work in private schools and only the males who work in government school hadn't quiet long experience in teaching field. This can imply that teachers whom monthly income exceeds 1000JD will be able to choose qualitative canned foods and are more likely to read the nutrition facts labels and won't bother for the price.

The data shows as well that $39.3 \%$ from the sample teach general science, $14.35 \%$ teach chemistry, $7.1 \%$ teach biology, $14.3 \%$ teach physics, $1.8 \%$ teaches geology and $23.2 \%$ teach other scientific subjects. The general science teachers are mostly interested in food related topics because they have to teach health subjects in their curriculum which makes them able to answer from their prior knowledge (Duffrin, 2010).

\section{Table 2 results:}

The association between the question (is canned foods as nutritious as fresh and frozen food?) and gender was statically 
significant $(\mathrm{p}<0.05)$. Most of the respondents gave $(\mathrm{No})$ answers (58.9\%), maybe (32.1\%), Yes (8.9\%), more males gave (No) answers (28.6\%) as compared to females (2.4\%), and this asserts the way that female science teachers think about canned foods thoughtfully more than male science teachers. Female teachers didn't prefer consuming canned foods regardless of what the food label facts said about it. On the other hand, male teachers did not show much interest in the nutrition facts on canned foods and the majority of them thought that it was as nutritious as fresh and frozen food. With regard to eating habits, a large number of reports indicate that in general, women are more aware about diet and health-diet relationship implications and also embrace suggested dietary changes to a greater degree than men. ( Arganini, Saba, Comitato, \& Virgili, 2014)

- The association between the question (Do you know how to choose canned foods by using the food labels on the back of the can?) and gender was not statically significant ( $>>0.05)$. Most of the respondents gave (Yes) answers (67.9\%), No (19.6\%), maybe (12.5\%).

Table (3) shows that:

- There was no statistically significant association regarding monthly income of the teachers. It is found from the result here that the income didn't affect the teachers' choice in canned foods. It is known in Jordan that canned foods isn't that expensive so most of the people consume it regularly.

Table 3: Science teacher's knowledge about nutritional facts of canned foods of different income

\begin{tabular}{|c|c|c|c|c|c|c|c|c|}
\hline No. & Question & Answer & $\begin{array}{l}\text { Less than } \\
500 \mathrm{JD}\end{array}$ & 500-1000 JD & $\begin{array}{l}\text { More than } \\
1000 J D\end{array}$ & Total & $\begin{array}{l}C \quad h \quad i \\
\text { square }\end{array}$ & p-value \\
\hline \multirow[t]{3}{*}{1} & \multirow{3}{*}{$\begin{array}{l}\text { Is canned foods as nutritious as fresh and } \\
\text { frozen food? }\end{array}$} & Yes & 0 & $1(3.7 \%)$ & $4(23.5 \%)$ & $5(8.9 \%)$ & 6.87 & 0.142 \\
\hline & & Maybe & $5(41.7 \%)$ & $9(33.3 \%)$ & $4(23.5 \%)$ & $18(32.1 \%)$ & & \\
\hline & & No & $7(58.3 \%)$ & $17(63 \%)$ & $9(52.9 \%)$ & $33(58.9 \%)$ & & \\
\hline \multirow[t]{3}{*}{2} & \multirow{3}{*}{$\begin{array}{l}\text { Do you know how to choose canned foods by } \\
\text { using the food labels on the back of the can? }\end{array}$} & Yes & $8(66.7 \%)$ & $18(66.7 \%)$ & $12(70.6 \%)$ & $38(67.9 \%)$ & 1.11 & 0.893 \\
\hline & & Maybe & $2(16.7 \%)$ & $4(14.8 \%)$ & $1(5.9 \%)$ & $7(12.5 \%)$ & & \\
\hline & & No & $2(16.7 \%)$ & $5(18.5 \%)$ & $4(23.5 \%)$ & $11(19.6 \%)$ & & \\
\hline \multirow[t]{3}{*}{3} & \multirow{3}{*}{$\begin{array}{l}\text { Do you know the difference between canned } \\
\text { tuna with oil and canned tuna with salty water? }\end{array}$} & Yes & $10(83.3 \%)$ & $18(66.7 \%)$ & $12(70.6 \%)$ & $40(71.4)$ & 4.06 & 0.398 \\
\hline & & Maybe & 0 & $3(11.1 \%)$ & 0 & $3(5.4 \%)$ & & \\
\hline & & No & $2(16.7 \%)$ & $6(22.2 \%)$ & $5(29.4 \%)$ & $13(23.2 \%)$ & & \\
\hline \multirow[t]{3}{*}{4} & \multirow{3}{*}{$\begin{array}{l}\text { Do you know how to read the labels on the } \\
\text { back of the canned foods? }\end{array}$} & Yes & $10(83.3 \%)$ & $20(74.1 \%)$ & $15(88.2 \%)$ & $45(80.4 \%)$ & 4.47 & 0.346 \\
\hline & & Maybe & $2(16.7 \%)$ & $3(11.1 \%)$ & 0 & $5(8.9 \%)$ & & \\
\hline & & No & 0 & $4(14.8 \%)$ & $2(11.8 \%)$ & $6(10.7 \%)$ & & \\
\hline \multirow[t]{3}{*}{5} & \multirow{3}{*}{$\begin{array}{l}\text { Have you ever counted the calories that the } \\
\text { canned foods provide for one meal? }\end{array}$} & Yes & $3(25 \%)$ & $11(40.7 \%)$ & $10(58.8 \%)$ & $24(42.9 \%)$ & 3.42 & 0.491 \\
\hline & & Maybe & $1(8.3 \%)$ & $2(7.4 \%)$ & $1(5.9 \%)$ & $4(7.1 \%)$ & & \\
\hline & & No & $8(66.7 \%)$ & $14(51.9 \%)$ & $6(35.3 \%)$ & $28(50 \%)$ & & \\
\hline \multirow[t]{3}{*}{6} & \multirow{3}{*}{$\begin{array}{l}\text { Do you think that canned foods are high in } \\
\text { sodium? }\end{array}$} & Yes & $7(58.3 \%)$ & $19(70.4 \%)$ & $10(58.8 \%)$ & $36(64.3 \%)$ & 3.74 & 0.443 \\
\hline & & Maybe & $5(41.7 \%)$ & $5(18.5 \%)$ & $6(35.3 \%)$ & $16(28.6 \%)$ & & \\
\hline & & No & 0 & $3(11.1 \%)$ & $1(5.9 \%)$ & $4(7.1 \%)$ & & \\
\hline \multirow[t]{3}{*}{7} & \multirow{3}{*}{$\begin{array}{l}\text { Have you ever taught your students facts about } \\
\text { canned foods? }\end{array}$} & Yes & $1(8.3 \%)$ & $6(22.2 \%)$ & $9(52.9 \%)$ & $16(28.6 \%)$ & 11.05 & $0.026^{*}$ \\
\hline & & Maybe & $5(41.7 \%)$ & $13(48.1 \%)$ & $7(41.2 \%)$ & $25(44.6 \%)$ & & \\
\hline & & No & $6(50 \%)$ & $8(29.6 \%)$ & $1(5.9 \%)$ & $15(26.8 \%)$ & & \\
\hline \multirow[t]{3}{*}{8} & \multirow{3}{*}{$\begin{array}{l}\text { Do you explain to your students the bad effects } \\
\text { of canned foods when over consumed? }\end{array}$} & Yes & $4(33.3 \%)$ & $15(55.6 \%)$ & $9(52.9 \%)$ & $28(50 \%)$ & 2.77 & 0.597 \\
\hline & & Maybe & $1(8.3 \%)$ & $1(3.7 \%)$ & $2(11.8 \%)$ & $4(7.1 \%)$ & & \\
\hline & & No & $7(58.3 \%)$ & $11(40.7 \%)$ & $6(35.3 \%)$ & $24(42.9 \%)$ & & \\
\hline \multirow[t]{3}{*}{9} & \multirow{3}{*}{$\begin{array}{l}\text { Do you think that the science curriculum } \\
\text { should contain lessons about food labels facts? }\end{array}$} & Yes & $10(83.3 \%)$ & $23(85.2 \%)$ & $17(100 \%)$ & $50(89.3 \%)$ & 3.86 & 0.426 \\
\hline & & Maybe & $2(16.7 \%)$ & $3(11.1 \%)$ & 0 & $5(8.9 \%)$ & & \\
\hline & & No & 0 & $1(3.7 \%)$ & 0 & $1(1.8 \%)$ & & \\
\hline \multirow[t]{3}{*}{10} & \multirow{3}{*}{$\begin{array}{l}\text { Do you think teaching information about food } \\
\text { labels will add long-life experience towards } \\
\text { healthy diets? }\end{array}$} & Yes & $9(75 \%)$ & $23(85.2 \%)$ & $16(94.1 \%)$ & $48(85.7 \%)$ & 3.51 & 0.476 \\
\hline & & Maybe & $3(25 \%)$ & $3(11.1 \%)$ & $1(5.9 \%)$ & $7(12.5 \%)$ & & \\
\hline & & No & 0 & $1(3.7 \%)$ & 0 & $1(1.8 \%)$ & & \\
\hline
\end{tabular}




\begin{tabular}{|c|c|c|c|c|c|c|c|c|}
\hline No. & Question & Answer & $\begin{array}{l}\text { Less than } \\
500 \mathrm{JD}\end{array}$ & $500-1000 \mathrm{JD}$ & $\begin{array}{l}\text { More than } \\
1000 \mathrm{JD}\end{array}$ & Total & $\begin{array}{l}C \quad h \quad i \\
\text { square }\end{array}$ & $p$-value \\
\hline \multirow[t]{3}{*}{11} & \multirow{3}{*}{$\begin{array}{l}\text { Through the COVID-19 crisis, do you think } \\
\text { that consuming more canned foods may cause } \\
\text { health issues for people? }\end{array}$} & Yes & $8(66.7 \%)$ & $15(55.6 \%)$ & $8(47.1 \%)$ & $31(55.4 \%)$ & \multirow[t]{3}{*}{6.37} & \multirow[t]{3}{*}{0.173} \\
\hline & & Maybe & $4(33.3 \%)$ & $8(29.6 \%)$ & $9(52.9 \%)$ & $21(37.5 \%)$ & & \\
\hline & & No & 0 & $4(14.8 \%)$ & 0 & $4(7.1 \%)$ & & \\
\hline \multirow[t]{3}{*}{12} & \multirow{3}{*}{$\begin{array}{l}\text { Do you think consuming more canned foods } \\
\text { cause health issues for people infected with } \\
\text { COVID-19 disease? }\end{array}$} & Yes & $6(50 \%)$ & $13(48.1 \%)$ & $2(11.8 \%)$ & $21(37.5 \%)$ & \multirow[t]{3}{*}{7.18} & \multirow[t]{3}{*}{0.127} \\
\hline & & Maybe & $5(41.7 \%)$ & $10(37 \%)$ & $11(64.7 \%)$ & $26(46.4 \%)$ & & \\
\hline & & No & $1(8.3 \%)$ & $4(14.8 \%)$ & $4(23.5 \%)$ & $9(16.1 \%)$ & & \\
\hline \multirow[t]{3}{*}{13} & \multirow[t]{3}{*}{ Does canned foods cause chronic diseases? } & Yes & $2(16.7 \%)$ & $6(22.2 \%)$ & $2(11.8 \%)$ & 1017.9\%) & \multirow[t]{3}{*}{1.31} & \multirow[t]{3}{*}{0.860} \\
\hline & & Maybe & $6(50 \%)$ & $14(51.9 \%)$ & $11(64.7 \%)$ & $31(55.4 \%)$ & & \\
\hline & & No & $4(33.3 \%)$ & $7(25.9 \%)$ & $4(23.5 \%)$ & $15(26.8 \%)$ & & \\
\hline \multirow[t]{3}{*}{14} & \multirow{3}{*}{$\begin{array}{l}\text { From your point of view as a science teacher, do } \\
\text { you think that canned foods have any genetic } \\
\text { effects on the new offspring? }\end{array}$} & Yes & $5(41.7 \%)$ & $6(22.2 \%)$ & $1(5.9 \%)$ & $12(21.4 \%)$ & \multirow[t]{3}{*}{5.72} & \multirow[t]{3}{*}{0.221} \\
\hline & & Maybe & $4(33.3 \%)$ & $10(37 \%)$ & $9(52.9 \%)$ & $23(41.1 \%)$ & & \\
\hline & & No & $3(25 \%)$ & $11(40.7 \%)$ & $7(41.2 \%)$ & $21(37.5 \%)$ & & \\
\hline \multirow[t]{3}{*}{15} & \multirow{3}{*}{$\begin{array}{l}\text { Do you recommend your colleagues to add } \\
\text { extra-curricular about health issues that help } \\
\text { their students to boost the immune system and } \\
\text { fight the new virus? }\end{array}$} & Yes & $7(58.3 \%)$ & $26(96.3 \%)$ & $17(100 \%)$ & $50(89.3 \%)$ & \multirow[t]{3}{*}{16.01} & \multirow[t]{3}{*}{$0.003^{\star}$} \\
\hline & & Maybe & $2(16.7 \%)$ & 0 & 0 & $2(3.6 \%)$ & & \\
\hline & & No & $3(25 \%)$ & 1(3.7\%) & 0 & $4(7.1 \%)$ & & \\
\hline \multirow[t]{3}{*}{16} & \multirow{3}{*}{$\begin{array}{l}\text { Have you ever explained to your students the } \\
\text { Bisphenol A that is present in canned foods? }\end{array}$} & Yes & $1(8.3 \%)$ & $2(7.4 \%)$ & $1(5.9 \%)$ & $4(7.1 \%)$ & \multirow[t]{3}{*}{1.17} & \multirow[t]{3}{*}{0.883} \\
\hline & & Maybe & 0 & $1(3.7 \%)$ & 0 & $1(1.8 \%)$ & & \\
\hline & & No & $11(91.7 \%)$ & $24(88.9 \%)$ & $16(94.1 \%)$ & $51(91.1 \%)$ & & \\
\hline
\end{tabular}

- The association between the question (Do you know how to choose canned foods by using the food labels on the back of the can?) and (gender, income) was not statically significant ( $\mathrm{p}>0.05)$. Most of the respondents gave (Yes) answers (67.9\%), No (19.6\%), maybe (12.5\%).

- The association between the question (Do you know the difference between canned tuna with oil and canned tuna with salty water?) and (gender, income) was not statically significant ( $\mathrm{p}>0.05)$. Most of the respondents gave (yes) answers (71.4\%), no (23.2\%), maybe (5.4\%).

- The association between the question (Do you know how to read the labels on the back of the canned foods?) and gender was statically significant $(\mathrm{p}<0.05)$. Most of the respondents gave (Yes) answers (80.4\%), No (10.7\%), maybe (8.9\%), more females gave (Yes) answers (85.7\%) as compared to males (64.3\%). Here the female teachers were specific in giving yes answer because they taught students how to read the food labels which made them more concerns to pick the correct canned foods.

- There was no statistically significant association regarding monthly income of the teachers. The income didn't affect the science teachers' nor health stream teachers' choices for food in general.

- The association between the question (Have you ever count the calories that the canned foods provides for one meal?) and (gender, income) was not statically significant $(\mathrm{p}>0.05)$. Most of the respondents gave (No) answers $(50.0 \%)$, Yes $(42.9 \%)$, maybe $(7.1 \%)$.

- The association between the question (Do you think that canned foods is high in sodium?) and (gender, income) was not statically significant $(\mathrm{p}>0.05)$. Most of the respondents gave (Yes) answers (64.3\%), maybe (28.6\%), No (7.1\%).

- The association between the question (Have you ever taught your students facts about canned foods?) and gender was not statically significant ( $\mathrm{p}>0.05)$. Most of the respondents gave (Maybe) answers (44.6\%) Yes (28.6\%), No $(26.8 \%)$. while there was statistically significant association regarding monthly income of the teachers. The data showed that most of the teachers' answers were "no" for teaching their students nutrition information or facts about canned foods labels. However, there was a statically significant association that teachers' salaries can affect their food choices in teaching canned foods. A study showed that teachers' salaries specially in private schools might affect their choices in using canned foods. This is because their income level will decide on and limit their food choices based on the prices of the items they can afford on a regular basis. Those choices in turn will be reflected in their teaching or even in the normal discussions with their students, thus influencing the students (Britton \& 
Proper, Teacher pay and school productivity: Exploiting wage regulation, 2016).

- The association between the question (Do you explain to your students the bad effects of canned foods when over consumed?) and (gender, income) was not statically significant ( $\mathrm{p}>0.05)$. Most of the respondents gave (Yes) answers (50.0\%), No (42.9\%), maybe (7.1\%).

- The association between the question (Do you think that the science curriculum should contain lessons about food labels facts?) and gender was statically significant $(\mathrm{p}<0.05)$. Most of the respondents gave (Yes) answers (89.3\%), maybe (8.9\%), No (1.8\%), more females gave (Yes) answers (95.2\%) as compared to males (71.4\%). while there was no statistically significant association regarding monthly income of the teachers.

- The association between the question (Do you think teaching information about food labels will add long-life experience towards healthy diets?) and (gender, income) was not statically significant $(\mathrm{p}>0.05)$. Most of the respondents gave (Yes) answers (85.7\%), maybe (12.5\%), No $(1.8 \%)$.

- The association between the question (Through the COVID-19 crisis, do you think that consuming more canned foods may cause health issues for people?) and (gender, income) was not statically significant ( $\mathrm{p}>0.05)$. Most of the respondents gave (Yes) answers (55.4\%), maybe (37.5\%), No (7.1\%).

- The association between the question (Do you think consuming more canned foods cause health issues for people infected with COVID-19 disease?) and (gender, income) was not statically significant ( $p>0.05)$. Most of the respondents gave (maybe) answers (46.4\%), Yes (37.5\%), No (16.1\%).

- The association between the question (Does canned foods cause chronic diseases?) and (gender, income) was not statically significant ( $\mathrm{p}>0.05)$. Most of the respondents gave (maybe) answers (55.4\%), No (26.8\%), Yes (17.9\%).

- The association between the question (From your point of view as a science teacher, do you think that canned foods has any genetic effects on the new off springs?) and (gender, income) was not statically significant ( $\mathrm{p}>0.05)$. Most of the respondents gave (maybe) answers (41.1\%), No (37.5\%), Yes (21.4\%).
- The association between the question (Do you recommend your colleagues to add extra-curricular about health issues that help their students to boost the immune system and fight the new virus?) and gender was not statically significant ( $\mathrm{p}>0.05)$. Most of the respondents gave (Yes) answers (89.3\%), No (7.1\%), maybe (3.6\%). while there was statistically significant association regarding monthly income of the teachers.

- The association between the question (Have you ever explained to your students the Bisphe3l A that is present in canned foods?) and (gender, income) was not statically significant ( $\mathrm{p}>0.05)$. Most of the respondents gave (No) answers (91.1\%), Yes (7.1\%), No (1.8\%).

\section{THE INTERVIEW:}

\section{Why you do/don't think that canned foods as nutritious as fresh and frozen food?}

Participants were given three options to describe their choice and to explain their disagreement or agreement in Table 4:

Table 4 shows that participants take in consideration their own knowledge about the canned foods. 5 of 10 teachers $(50 \%$ of the sample) were not sure about their answers. Only two of them who revealed that canned foods as nutritious as fresh and frozen food regarding his experience in nursing field and that monthly income wasn't significant here since all the teachers were chosen has the same range of monthly income.

\section{Do you know how to read the labels on the back of the canned foods?}

To answer this question, the questionnaire items were divided into the following sections in Table 5:

The table 5 shows that $50 \%$ of female teachers (who four of them work in private schools and one in government school) knew the difference between canned tuna with oil and canned tuna with salty water and this knowledge were known to them through special extra curricula programs in the school they had to teach. According to the American Health Association, it is recommended that people use canned tuna with water better when it comes to omega- 3 fats that can reduce the risk of heart attacks and strokes (Dowden, 2020).

In the question: Have you ever taught your students facts about canned foods? $20 \%$ only agreed that they did talk

\begin{tabular}{|c|c|c|c|c|}
\hline Reasons to agree or disagree & M: Male & F: Female & I: Income & $\begin{array}{l}\text { School: } \underline{P}: \text { private, } \\
\underline{\text { G: Government }}\end{array}$ \\
\hline $\begin{array}{l}\text { Disagree it is the same. I think the process to make canned foods contains heating } \\
\text { which make it without vitamins. }\end{array}$ & 0 & 2 & $500-1000$ & Private \\
\hline $\begin{array}{l}\text { Agree. Canned foods were used at time of wars and through medical } \\
\text { reports I never heard any soldiers suffered from vitamin deficiencies. }\end{array}$ & 3 & 0 & $500-1000$ & Private \\
\hline I am not sure, because I never studied or taught that subject. & 2 & 3 & $500-1000$ & Government \\
\hline
\end{tabular}


I: Monthly Income: a: 500, b: 500-1000, SC.: School: ...P = number of private school members / ......G = number of Government school members.

\begin{tabular}{|c|c|c|c|c|c|c|c|c|c|c|c|c|c|c|c|c|c|c|}
\hline \multirow[b]{2}{*}{ Items } & \multicolumn{6}{|c|}{ Agree to a high level } & \multicolumn{6}{|c|}{$\begin{array}{l}\text { Agree to a } \\
\text { middle level }\end{array}$} & \multicolumn{6}{|c|}{ Disagree } \\
\hline & $\begin{array}{l}F \\
(\%)\end{array}$ & I & SC. & $\begin{array}{l}\text { M } \\
(\%)\end{array}$ & I & SC. & $\begin{array}{l}F \\
(\%)\end{array}$ & $\mathbf{I}$ & SC. & $\begin{array}{c}\text { M } \\
(\%)\end{array}$ & I & SC. & $\begin{array}{c}F \\
(\%)\end{array}$ & I & SC. & $\begin{array}{c}\text { M } \\
(\%)\end{array}$ & $\mathbf{I}$ & SC. \\
\hline $\begin{array}{l}\text { - Do you know the difference } \\
\text { between canned tuna with oil } \\
\text { and canned tuna with salty wa- } \\
\text { ter? }\end{array}$ & 50 & $\mathrm{a}$ & $\begin{array}{l}4 \mathrm{P} \\
1 \mathrm{G}\end{array}$ & 10 & $\mathrm{~b}$ & $1 \mathrm{G}$ & 0 & & & 0 & & & $0 \%$ & & & 40 & $\mathrm{~b}$ & $\begin{array}{l}1 \mathrm{P} \\
3 \mathrm{G}\end{array}$ \\
\hline $\begin{array}{l}\text { - Do you think that canned foods } \\
\text { are high in sodium? }\end{array}$ & 40 & $\mathrm{a}, \mathrm{b}$ & $\begin{array}{l}2 \mathrm{P} \\
2 \mathrm{G}\end{array}$ & 20 & $\mathrm{~b}$ & $2 \mathrm{P}$ & 10 & a & $1 \mathrm{G}$ & 0 & & & 0 & & & 30 & $\mathrm{a}$, & $\begin{array}{l}1 \mathrm{P} \\
2 \mathrm{G}\end{array}$ \\
\hline $\begin{array}{l}\text { - Have you ever taught your stu- } \\
\text { dents facts about canned foods? }\end{array}$ & 20 & $\mathrm{~b}$ & $2 \mathrm{P}$ & 0 & & & 10 & $\mathrm{~b}$ & $1 \mathrm{P}$ & 0 & & & 20 & $\mathrm{~b}$ & $2 \mathrm{G}$ & 50 & $\mathrm{a}$, & $\begin{array}{l}2 \mathrm{P} \\
3 \mathrm{G}\end{array}$ \\
\hline $\begin{array}{l}\text { - Through the COVID- } 19 \text { crisis, } \\
\text { do you think that consuming more } \\
\text { canned foods may cause health is- } \\
\text { sues for people? }\end{array}$ & 40 & $\mathrm{a}$ & $4 \mathrm{P}$ & 0 & & & 0 & & & 0 & & & 10 & $\mathrm{~b}$ & $1 \mathrm{P}$ & 50 & $\mathrm{~b}$ & $5 \mathrm{G}$ \\
\hline $\begin{array}{l}\text { - Does canned foods cause chronic } \\
\text { diseases? }\end{array}$ & 0 & & & 0 & & & 10 & $\mathrm{a}$ & $1 \mathrm{P}$ & 0 & & & 50 & $\mathrm{a}$ & $\begin{array}{l}2 \mathrm{P} \\
3 \mathrm{G}\end{array}$ & 40 & $\mathrm{a}$, & $\begin{array}{l}2 \mathrm{P} \\
2 \mathrm{G}\end{array}$ \\
\hline $\begin{array}{l}\text { - Have you ever explained to your } \\
\text { students the Bisphenol A that is } \\
\text { present in canned foods? }\end{array}$ & 0 & & & 0 & & & 10 & b & $1 \mathrm{G}$ & 20 & $\mathrm{a}$ & $\begin{array}{l}1 \mathrm{P} \\
1 \mathrm{G}\end{array}$ & $40 \%$ & $\mathrm{~b}$ & $\begin{array}{l}3 \mathrm{P} \\
1 \mathrm{G}\end{array}$ & 30 & $\mathrm{~b}$ & $\begin{array}{l}1 \mathrm{P} \\
3 \mathrm{G}\end{array}$ \\
\hline $\begin{array}{l}\text { - Through the COVID-19 crisis, } \\
\text { do you think that consuming more } \\
\text { canned foods may cause health is- } \\
\text { sues for people? }\end{array}$ & 0 & & & 0 & & & 10 & $\mathrm{a}$ & $1 \mathrm{P}$ & 20 & $\mathrm{~b}$ & $2 \mathrm{P}$ & 40 & $\mathrm{~b}$ & $\begin{array}{l}1 \mathrm{P} \\
3 \mathrm{G}\end{array}$ & 30 & $\mathrm{~b}$ & $2 \mathrm{G}$ \\
\hline
\end{tabular}

about canned foods through extra curricula science classes specifically in international schools from published document from the FDA electronic website (FDA, 2017), but $70 \%$ of the teachers with different monthly incomes in private and government schools disagree to mention the nutrition facts in any lesson at school curriculum that they taught claiming there is no need to add them in their science lessons.

Table 5 shows that $40 \%$ of female teachers recommended to teach their students the correct information about food labels that contains the nutrition facts, which might boost their immune system specially for canned foods that they used to eat and consume at the time of quarantine days which is shown in the question: Through the COVID-19 crisis, do you think that consuming more canned foods may cause health issues for people?. The $40 \%$ of female teachers believed consuming canned foods without reading the nutrition facts may affect student's immune system and if they knew how to read them, their choices will prevent them from having chronic diseases, but $60 \%$ of teachers didn't confirm that canned foods might affect their immune system and health through the crisis of COVID-19 virus $10 \%$ of them are female teachers and $50 \%$ are male teachers. There was no significant association regarding the monthly income and canned foods choices because the 60 $\%$ of teachers were having monthly income from $500-1000$ JD.
It is well known that there are differences in curriculum between private and government schools in Jordan regarding the nutrition and dietitian information, a study showed that obesity through adolescents in private schools in Jordan is reduced through teaching the concept of good food and lifestyle choices which is part of the mentioned subject reading fact nutrition labels on canned foods to make good choice ( Tayyem, Al-Hazzaa, Abu-Mweis, Bawad, \& Hammad, 2014).

\section{Implication and Limitations of the Study}

This study provided new outlooks and insights regarding Science Teachers' Knowledge of Nutrition Facts on Canned foods and its implications during the COVID-19 Pandemic in Jordan as a developing country with relatively lowincome levels and expensive living costs. The result showed significant differences between male and female teachers in their perceptions about canned foods. Furthermore, female science teachers were found to be more aware of the importance of reading food labels and also in transferring that to their students.

When the knowledge and information reach to teacher eventually, it will reach for the students in different levels at primary as well secondary and high school students. This would help them to adapt healthy lifestyles even at time of 
pandemics. Clearly, there were significant differences for some questions between male and female teachers, but there were no significant that is related to the income since most teachers can have different food choices at the market especially through the period of COVID-19 epidemic. Mostly countries were trying to complete the wheel of teaching and learning using the available online resources instead of focusing on the materials provided in different levels of various subjects' curricula, more to explain a research released by the OECD at the same year of the pandemic 2020 aimed to provide educators and teachers enormous digital resources that might help educators around the world in pre-school till high school level for the basics needed in each level, but when you go through these resources you get more information that non-science digital resources provided any nutrition facts about canned foods that teachers neither educators can use in their classes. (Reimers, Schleicher, Saavedra, \& Tuominen, 2020)

\section{CONCLUSION}

It is important to acknowledge that this survey has a limitation as it is a case study in Jordan, and this lessens the generalization of the findings. The findings of the current study also reveal the other side of the truth, that the economic and healthily wellbeing of teachers is cornerstone to the overall wellbeing of the society and future generations. Moreover, as science teachers are the main link between the present and the future in the information age, more attention should be devoted to improving their wellbeing, awareness and adoption of healthy lifestyles.

All in all, the current study reveals that reading food and nutrition labels goes way beyond the mere observation of written facts and is much more important than what most people think. Therefore, teachers should be empowered and encouraged to become more aware of their deists and eating habits, in addition to having thoughtful and intentional discussions with their students about the various related topics.

For researchers and practitioners, further studies should be conducted in other contexts. Researchers also could investigate the benefits and challenges of adding extra curricula materials for science resources to teach canned foods and healthy life diets. More lessons about how to avoid chronic diseases especially at the COVID-19 epidemic. They could also do more research adding different variables in the study such as city and suburbs, teachers from different subject fields etc.

\section{References}

Administration, F. c. (2010). Food act and regulations of Sri Lanka. Sri Lanka: Ministry of healthcare and nutrition.

Aldahmash, P. A., \& others. (2019). Trends in In-service Science Teacher Professional Development. International Journal of Instruction, 163-178.
Arganini, C., Saba, A., Comitato, R., \& Virgili, F. (2014). Gender Differences in Food Choice and. Rome, Italy: (National Research Institute for Food and Nutrition).

Atay, E., Göktaş, S., Öztürk Emiral, G., Dağtekin, G., Akbulut Zencirci, S., Aygar, H., et al. (2018). The health literacy level and eating behaviours of the teachers working at the city center of Eskisehir Turkey. International Journal of Research in Medical Sciences, 6(1), 27-34.

Atli Arnarson, P. (2017, February 16). The Fat-Soluble Vitamins: $A, D, E$ and $K$. Retrieved from healthline.com: https://www. healthline.com/nutrition/fat-soluble-vitamins

Bracale, R., \& Vaccarob, C. (2020). Changes in food choice following restrictive measures due to Covid-19. Nutrition, Metabolism and Cardiovascular Diseases, 30(9), 1423-1426.

Britton, J., \& Proper, C. (2015, 12 17). Journal of Public Economics. Eastern MediterraneanHealth Journal, pp. pages 75 -89.

Britton, J., \& Proper, C. (2016). Teacher pay and school productivity: Exploiting wage regulation. Journal of Public Economics, 133, pp. $75-89$.

BROWN, M. (2020, May 15). Diabetes warning: More than THIRD of COVID-19 hospital deaths had disease. Retrieved July 1, 2020, from EXPRESS: https://www.express.co.uk/life-style/ health/1282469/diabetes-coronavirus-covid-19-healthwarning

Choi, M.-K., Bae, Y.-J., Kim, M.-H., \& In, S.-J. (2010). A Survey of the Needs of Nutrition Education Based on Analysis of Eating Habits and Nutrition Knowledge among Middle School Students in Kyung-Gi Province. Journal of the Korean Dietetic Association, 16(2), 133-145.

Di Renzo, L., Gualtieri, P., Cinelli, G., Bigioni, G., Soldati, L., Attinà, A., et al. (2020). Psychological Aspects and Eating Habits during COVID-19 Home Confinement: Results of EHLC-COVID-19 Italian Online Survey. Nutrients(12), 7.

Diachenko, G. O. (2011, May 20). Concentration of Bisphenol A in Highly Consumed Canned foodss on the U.S. Market. Retrieved from ACSpublications: https://pubs.acs.org/doi/10.1021/ jf201076f

Donaldsons, G. (2010). Teaching Scotland's Future: Report of a review of teacher education in Scotland. Edinburgh: ScotGov.

Dowden, Angela (2020, January 2). Retrieved June 2021, from Stronglive.com: https://www.livestrong.com/article/362185tuna-in-oil-vs-tuna-in-water/

Duffrin, W. Melani. Using Food as a Tool to Teach Science to 3rd Grade Students in Appalachian Ohio. Retrieved June 2021, from Wiley online Library:

https://onlinelibrary.wiley.com/doi/full/10.1111/j.15414329.2010.00090.x

FDA.gov (2017, July). Science and our Food supply; Teacher's Guide for Middle Level Classrooms document Retrieved June 2021, from: https://www.fda.gov/media/90666/download

Fordyce-Voorham, Sandra. (2011, July 23). Identification of Essential Food Skills for Skill-based Healthful Eating Programs in Secondary Schools. Retrieved June 2021, from Elsevier.com: https://www.researchgate.net/journal/Journal-of-NutritionEducation-and-Behavior-1708-8259

Findholt, N., Izumi, B., Shannon, J., \& Naguyen, T. (2016). FoodRelated Practices and Beliefs of Rural US Elementary and Middle School Teachers. Rural and Remote Health, 16(2). 
Harris, L. R., \& Brown, G. T. (2010). Mixing interview and questionnaire methods: Practical problems in aligning data. Practical Assessment, Research, and Evaluation, 15(1).

Health Literacy Basics. (2020). Retrieved September 2020, from Centers for Disease Control and Prevention: https://www.cdc. gov/healthliteracy/learn/index.html

Institute of Medicine. (2005). Committee on prevention of obesity in children and youth. Washington, DC, USA,: National Academies Press.

Jane Brown, P. R. (2017, June 15). Fresh vs Frozen Fruit and Vegetables - Which Are Healthier? Retrieved from healthline.com: https:/www.healthline.com/nutrition/fresh-vs-frozen-fruitand-vegetables

Karen P.Penner, K. M. (1983). Secondary teachers' nutrition knowledge, attitudes, and practices. Journal of Nutrition Education, 15(04).

King, J. C. (2003). Contributions of Women to Human Nutrition. The Journal of Nutrition, 133(11), 3693-3697.

Kubik, M., Lytle , L., Hannan, P., Story , M., \& Perry, C. (2009). Food-Related Beliefs, Eating Behavior, and Classroom Food Practices of Middle School Teachers. Journal of School Health, 72(8), 339-345.

Lee, J.-S., \& Kim, N.-Y. (2009). A Study on Perception and Utilization of Food-Nutrition Labeling by Age in Busan residents. Journal of the Korean Society of Food Science and Nutrition, 38(12), 1801-1810.

Lewis , M., Brun, J., Talmage, H., \& Rasher, S. (1988). Teenagers and food choices: The impact of nutrition education. Journal of Nutrition Education, 20(6), 336-340.

Mansour., N. (2020). The dissonance between scientific evidence, diversity and dialogic pedagogy in the science classroom. International Journal of Science Education, 190 -217.

Mao , F. (2020, March 04). Coronavirus panic: Why are people stockpiling toilet paper? Retrieved from BBC News: https:// www.bbc.com/news/world-australia-51731422

Mertoglu, H. (2019). Effects of Interdisciplinery Nutrition Education on Prospective Science Teachers' Development of Healthy Life Style Behaviours. Journal of Education and Training Studies, $7(12)$.

Metos, J., Sarnoff, K., \& Jordan, K. (2018). Teachers' Perceived and Desired Roles in Nutrition Education. Journal of School Health, 89(1), 68-76.

Montagna Sekiyama, F., Rodrigues, R., Eumann Mesas, A., Durán González, A., \& Maffei de Andrade, S. (2009). Reading the Nutritional Information on Food Labels Among Teachers with and without Hypertension in Brazil. International Journal of Preventive Medicine, 10(1).
Mutlu, A.,Şeşen, B.A. (2020). Comparison of inquiry-based instruction in real and virtual laboratory environments: Prospective science teachers' attitudes.International Journal of Curriculum and Instruction. 12(2), 600-617.

Netto Rangel, C., Nunn, R., Dysarz, F., Silva, E., \& Brasil Fonseca, A. (2014). Teaching and learning about food and nutrition through science education in Brazilian schools: an intersection of knowledge. SciELO Public Health.

Petresen, M., \& Kies, C. (1971). Nutrition knowledge and attitudes of early elementary teachers. Journal of Nutrition Education, 4(1), 11-15.

Pietrangelo, A. (2019, May 28). Understanding type2 diabetes. Retrieved from healthline.com: https://www.healthline.com/ health/type-2-diabetes

Pilcher RW, C. B. (1949, June 13). Nutrient Retention During Canned foods Production. Retrieved from NCBI resources: https://www. ncbi.nlm.nih.gov/pmc/articles/PMC1528152/

Reimers, Fernando M.; Schleicher, Andreas; Saavedra, Jaime; Tuominen, Saku (2020, March 29). Supporting the continuation of teaching and learning during the COVID-19 Pandemic Annotated resources for online learning. Retrieved in 2021, June 23 from the OECD resources:

https://www.oecd.org/education/Supporting-the-continuation-ofteaching-and-learning-during-the-COVID-19-pandemic.pdf

Scarmozzino , F., \& Visioli , F. (2020). Covid-19 and the Subsequent Lockdown Modified Dietary Habits of Almost Half the Population in an Italian Sample. Foods, 9(5).

Sekiyama, F. M. (2019, January 15). Reading the Nutritional Information on Food Labels Among Teachers with and without Hypertension in Brazil. Retrieved June 25, 2020, from PubMed: https://pubmed.ncbi.nlm.nih.gov/30774835/

Şahin-Kalyon, D. (2021). Teaching Science: Who am I? What do I plan. International Online Journal of Education and Teaching (IOJET), 8(3). 2150-2175.

Tayyem, R. F., Al-Hazzaa, H. M., Abu-Mweis, S. S., Bawad, H. A., \& Hammad, S. S. (2014, 2 4). Dietary habits and physical activity levels in Jordanian. Eastern MediterraneanHealth Journal, pp. Vol. 20 : page 416 - 422 .

Unusan, N. (2004). Preschool teachers' attitudes towards nutritional information on food labels in Turkey and recommendations for an educational programme. Early Child Development and Care, 174(7-8).

World Health Organization. (2020, 3 11). WHO Director-General's opening remarks at the media briefing on COVID-19-11 March 2020. Retrieved 3 13, 2020, from World Health Organization: https://www.who.int/dg/speeches/detail/who-director-generals-opening-remarks-at-the-media-briefing-on-covid-19---11march-2020 